\title{
EFEKTIFITAS BAHAN AJAR EKOLOGI HEWAN BERBASIS PROBLEM BASED LEARNING TERHADAP KEMAMPUAN BERPIKIR KRITIS DAN PEMECAHAN MASALAH MAHASISWA PENDIDIKAN BIOLOGI
}

\author{
Setyoko ${ }^{1}$ \\ Indriaty $^{2}$ \\ T Hadi Wibowo $\mathbf{A}^{3}$ \\ ${ }^{1,2,3}$ Program Studi Pendidikan Biologi, FKIP Universitas Samudra, Kota Langsa, Provinsi \\ Aceh \\ E-mail: ${ }^{1}$ setyoko@unsam.ac.id, ${ }^{2}$ indriaty@unsam.ac.id, \\ 3 teukuhadiwibowoatmaja@unsam.ac.id
}

\begin{abstract}
Learning in higher education requires students to master competencies in accordance with their fields of expertise. Animal ecology teaching materials that are designed with a problem based learning approach can encourage students to stimulate critical thinking and problem solving in the surrounding environment. This study aims to determine the effectiveness of animal-based learning materials based on Problem Based Learning $(P B L)$ on the ability to critically and solve the problem of students of Biology Education FKIP Universitas Samudra. Quasi Experiment research method with Posttest Only Non Equivalent Control Group Design design. Research sample with Purposive Sampling technique. The research instrument using C3-C6 stratified essay test is validity test, reliability test. Data analysis using One Sample t-test statistic test with Prerequisite of data Normality. Result of research of critical thinking ability based on one sample test $t$ test Sig (2 tailed) $(0,00) \leq \alpha(0,05)$ with Ha accepted, significant difference of result of critical thinking ability of student by using animal based ecology based on problem based learning. Sig $(2$-tailed $)(0.00) \leq \alpha(0,05)$ problem solving ability with Ha accepted; significant difference in the result of students' problem solving ability using animal based ecological learning based problem learning. Effectiveness Animal-based animal-based learning materials can improve students' critical thinking and problem solving skills in Biology Education at FKIP Universitas Samudra.
\end{abstract}

Kata Kunci: Critical Thinking, Problem Based Learning, Problem Solving, Teaching Materials

\section{PENDAHULUAN}

Pendidikan Tinggi dihadapkan pada problematika era globalisasi yang kompleks, mahasiswa dituntut harus memenuhi tujuan dan sasaran pencapaian pembelajaran sesuai dengan kompetensi bidang yang dipelajari. Mahasiswa dapat mengaplikasikan pengetahuan keilmuwan yang dipelajari dalam kehidupan sehari-hari sesuai dengan kompetensi yang dibutuhkan oleh pasar kerja. Kondisi relaitas dilapangan saat ini dengan ketersediaan sumber belajar yang sudah tidak terbatas diera digital, mahasiswa dapat mengakses sumber- sumber belajar yang digunakan dalam pembelajaran sepeti; sumber internet website, jurnal, e-books dan sumber belajar lainnya.

Hasil observasi yang dilakukan terhadap mahasiswa pendidikan biologi FKIP Universitas Samudra, belum sepenuhnya dapat mengintergasikan sumber-sumber rujukan pembelajaran dapat menstimulasi kemampuan mahasiswa dalam berpikir kritis dan memecahkan permasalahan sesuai permasalahan saat ini. Salah satu upaya yang dapat dilakukan sebagai strategi terbosoan dalam kegiatan pembelajaran pada matakuliah ekologi hewan dengan mengembangkan bahan ajar berorientasi 
pada permasalahan dilingkungan nyata bagi mahasiswa melalui pengembangan bahan ajar berbasis problem based learning. Kegiatan pembelajaran biologi melalui pendekatan ilmiah membangun siswa untuk memperoleh pengetahuan yang baru, keterampilan dan sikap ilmiah (Toy, dkk. 2018).

Pengembangan bahan ajar berbasis problem based learning diharapkan memberikan dorongan kepada mahasiswa dalam penguasaan teori yang aplikatif dibidang keilmuwan ekologi hewan. Bahan ajar kontekstual yang digunakan dapat mencapai kompetensi dan tujuan pembelajaran sesuai dengan target capaian kurikulum. Bahan ajar berbasis problem based learning mendorong mahasiswa mempelajari permasalahan sekitar, sehingga memberikan stimulus kemampuan bepikir kritis dan pemecahan masalah dari realita permasalahan nyata. Pembelajaran problem based learning memacu mahasiswa melakukan penelitian dilapangan secara langsung untuk memperoleh jawaban dari permasalahan nyata yang ditemui dalam pembelajaran dikelas (Nurhayati, dkk., 2019).

Mahasiswa dapat berinteraksi secara langsung, sehingga membentuk pondasi dasar bagi mahasiswa dalam kemampuan berpikir kritis dan dalam pemecahan masalah sesuai dengan kondisi lingkungan nyata. Bahan ajar ini menggali kondisi alam sekitar yang dijadikan sebagai sumber dalam pembelajaran. Bahan ajar yang sesuai dengan kondisi, akan mendorong penguasaan mahasiswa dalam memahami materi terhadap kompetensi materi pembelajaran (Purwanto., dkk., 2007).

Bahan ajar berbasis problem based lerning yang dibuat sesuai dengan kebutuhan mahasiswa dapat mendorong ketercapaian kompentensi yang diharapkan. Pembelajaran Problem Based Learning bertujuan membantu berpikir kritis dan pemecahan masalah dan membangun situasi nyata yang berdasarkan atas konsep yang dipelajari (Bilgin, dkk., 2009).

Pembelajaran menggunakan bahan ajar seperti modul dapat melatih keterampilan berpikir kritis berbeda dengan pembelajaran yang tidak menggunakan bahan ajar modul (Wijayanti dan Nawawi, 2017). Pembelajaran yang diangkat berdasarkan keadaan nyata dijadikan sebagai bahan ajar seperti lembar kerja siswa berbasis masalah pembelajaran menjadi efektif dan optimal dalam meningkatkan kemampuan pemecahan masalah (Tivani, dan Paidi, 2016).

Pengembangan bahan ajar berbasis problem based learning dibuat berdasarkan kajian dari keadaan lingkungan sekitar, diharapakan secara keefektif meningkatkan kemampuan mahasiswa dalam berpikir kritis dan memecahkan masalah. Tujuan penelitian ini mengetahui efektifitas bahan ajar ekologi hewan berbasis problem based learning pada mahasiswa Pendidikan Biologi FKIP Universitas Samudra.

\section{METODE}

Metode dalam penelitian ini Quasi Experiment dengan desain Posttest Only Non Equivalent Control Group Design, dengan uji efektifitas bahan ajar terhadap kemampuan berpikir kritis dan pemecahan masalah mahasiswa. Penelitian ini dilaksanakan pada Mahasiswa Program Studi Pendidikan Biologi semester VI yang menempuh matakuliah Ekologi Hewan, di Fakultas Keguruan dan Ilmu Pendidikan Universitas Samudra. Waktu pelaksanaan penelitian akan dilakukan pada bulan September sampai dengan Desember 2017. Populasi dalam penelitian ini mahasiswaPendidikan Biologi berjumlah 60 mahasiswa yang Sampel dalam penelitian ini mahasiswa berjumlah 30 mahasiswa yang sudah menempuh matakuliah Ekologi Hewan. 
Populasi dan sampel penelitian pada mahasiswa Pendidikan Biologi FKIP Universitas Samudra melalui teknik Purposive Sampling.

Instrument penelitian untuk mengukur kemampuan berpikir kritis dan pemecahan masalah menggunakan soal Essay $\mathrm{C}_{4}$ sampai $\mathrm{C}_{6}$ dan lembar observasi. Perangkat pembelajaran yang digunakan Bahan Ajar Ekologi Hewan berbasis Problem based Learning, Rencana Program Semester (RPS), Satuan Acara Perkualiah (SAP), Panduan Praktikum Ekologi Hewan. Analisis data Instrument penelitian berupa soal essay dengan tingkat $\mathrm{C}_{3}$ dan $\mathrm{C}_{6}$ dilakukan uji validitas, uji reliabilitas, daya beda dan tingkat kesulitan soal menggunakan softwere Anates 3.2. Analisis data hasil berpikir kritis dan pemecahan masalah Belajar mahasiswa menggunakan uji statistik one sample t-test dengan uji prasyarat Nomalitas data kolmogorove smirnov untuk mengetahui distribusi data. Analisis data menggunakan softwere SPSS for windows 2.1. Hipotesis penelitian Jika $\mathrm{t}$ hitung $\geq \mathrm{t}$ tabel maka $\left(\mathrm{H}_{\mathrm{o}}\right)$ ditolak dan $\left(\mathrm{H}_{\mathrm{a}}\right)$ diterima, atau Jika $\mathrm{t}_{\text {hitung }}<\mathrm{t}$ tabel maka $\left(\mathrm{H}_{\mathrm{o}}\right)$ diterima dan $\left(\mathrm{H}_{\mathrm{a}}\right)$ ditolak.

\section{HASIL}

\section{Kemampuan Berpikir Kritis}

Kemampuan berpikir kritis mahasiswa pendidikan biologi berdasarkan efektifitas bahan ajar ekologi hewan berbasis problem based learning didasarkan pada hasil analisis uji validitas dan uji reliabilitas diperoleh rata-rata nilai 81,04, Standar Deviasi $(9,20)$, Validitas; 0,20 (kriteria validitas rendah) dan Reliabilitas; 0,85 (kriteria reliabilitas tinggi), dapat dilihat pada Tabel 1. Hasil Uji Normalitas Data menunjukan Sig $(0,200) \geq \alpha(0,05)$ dengan demikian $\mathrm{H}_{0}$ Diterima, artinya data berdistribusi normal, data dapat dilihat pada Tabel 2. Hasil statistik Deskriptif menunjukan Nilai Rata-rata; 81,03 dengan Standar Deviasi; 9,20. Data berdistribusi Normal, maka dilanjutkan uji hipotesis menggunakan uji one sample t-test, dengan Sig (2 -tailed) $(0,00) \leq \alpha \quad(0,05)$ dengan demikian $\mathrm{H}_{\mathrm{a}}$ diterima, signifikan perbedaan rata hasil kemampuan berpikir kritis mahasiswa dengan menggunakan bahan ajar ekologi hewan berbasis problem based learning. Ringkasan uji one sample $t$ test dapat dilihat Tabel 3 dan Tabel 4.

\section{Kemampuan Pemecahan Masalah}

Kemampuan pemecahan masalah mahasiswa pendidikan biologi berdasarkan efektiftas bahan ajar ekologi hewan berbasis problem based learning didasarkan pada hasil analisis uji validitas dan uji reliabilitas diperoleh rata-rata nilai 80,68 , Standar Deviasi $(8,73)$, Validitas; 0,87 (kriteria validitas tinggi) dan Reliabalitas; 0,93 (kriteria reliabilitas sangat tinggi), dapat dilihat pada Tabel 5. Hasil uji normalitas data menunjukan Sig $(0,200) \simeq \chi(0,05)$ dengan demikian $\mathrm{H}_{0}$ Diterima, artinya data berdistribusi normal, data dapat dilihat pada Tabel 6. Hasil Statistik Deskriptif menunjukan Nilai Rata-rata; 80,67 dengan Standar Deviasi; 8,73. Berdasarkan uji one sample t-test Sig (2 tailed) $(0,00) \leq \alpha(0,05)$ dengan demikian $\mathrm{H}_{\mathrm{a}}$ diterima; signifikan perbedaan rata hasil kemampuan pemecahan masalah mahasiswa dengan menggunakan bahan ajar ekologi hewan berbasis problem based learning. Ringkasan uji one sample $t$ test dapat dilihat Tabel 7 dan Tabel 8. 
Tabel 1. Uji Validitas dan Reliabilitas

\begin{tabular}{lllc}
\hline Rata-rata & SD & Korelasi XY & Reliabilitas \\
\hline 81,04 & 9,20 & 0,20 & 0,85 \\
\hline
\end{tabular}

Tabel 2.Uji Normalitas Data Sampel

\begin{tabular}{cccccccr}
\hline & \multicolumn{3}{c}{ Kolmogorov-Smirnov $^{\mathrm{a}}$} & \multicolumn{3}{c}{ Shapiro-Wilk } \\
\cline { 2 - 8 } Berpikir Kritis & Statistic & $\mathrm{df}$ & Sig. & Statistic & $\mathrm{df}$ & \multicolumn{1}{c}{ Sig. } \\
&, 101 & 28 &, $200^{*}$ &, 984 & 28 &, 938 \\
\hline
\end{tabular}

Tabel 3.Uji Statistik Deskriptif

\begin{tabular}{lllll}
\hline & N & Mean & Std. Deviation & Std. Error Mean \\
\hline Berpikir Kritis & 28 & 81,0357 & 9,20339 & 1,73928 \\
\hline
\end{tabular}

Tabel 4.Uji t One Sample T-Test

\begin{tabular}{|c|c|c|c|c|c|c|}
\hline \multirow{2}{*}{+2} & \multirow[t]{2}{*}{$\mathrm{t}$} & \multirow[t]{2}{*}{ df } & \multirow{2}{*}{$\begin{array}{l}\text { Sig. (2- } \\
\text { tailed) }\end{array}$} & \multirow{2}{*}{$\begin{array}{l}\text { Mean } \\
\text { Difference }\end{array}$} & \multicolumn{2}{|c|}{ 95\% Confidence Interval } \\
\hline & & & & & Lower & Upper \\
\hline Berpikir Kritis & $-10,904$ & 27 &, 000 & $-18,96429$ & $-22,5330$ & $-15,3956$ \\
\hline
\end{tabular}

Tabel 5.Ringkasan Uji Validitas dan Reliabilitas

\begin{tabular}{llll}
\hline Rata-rata & SD & Korelasi XY & Reliabilitas \\
\hline 80,68 & 8,73 & 0,87 & 0,93 \\
\hline
\end{tabular}

Tabel 6.Uji Normalitas Data Sampel

\begin{tabular}{lccccccc}
\hline & \multicolumn{3}{c}{ Kolmogorov-Smirnov $^{\text {a }}$} & \multicolumn{3}{c}{ Shapiro-Wilk } \\
\cline { 2 - 8 } Pemecahan Masalah & Statistic & df & & Sig. & Statistic & df & \multicolumn{1}{c}{ Sig. } \\
&, 112 & & 28 &, $200^{*}$ &, 958 & 28 &, 314 \\
\hline
\end{tabular}

Tabel 7.Statistik Deskriptif

\begin{tabular}{lllrr}
\hline & N & Mean & Std. Deviation & \multicolumn{1}{c}{ Std. Error Mean } \\
\hline Pemecahan Masalah & 28 & 80,6786 & 8,73076 & 1,64996 \\
\hline
\end{tabular}

Tabel 8.Uji t One Sample T-Test

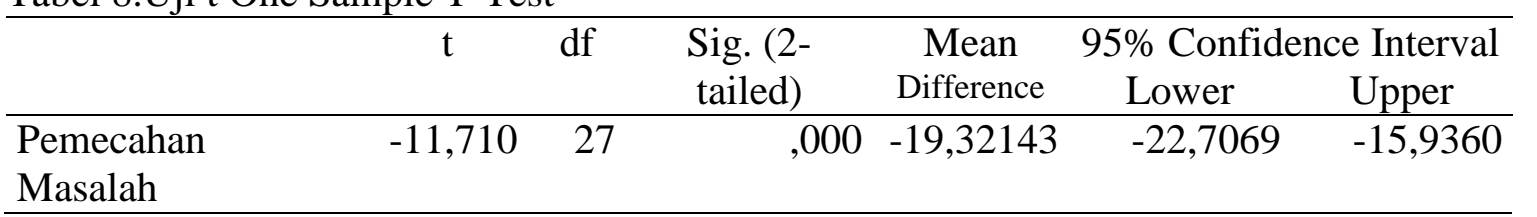

\section{PEMBAHASAN}

Kemampuan berpikir kritis mahasiswa dibangun tidak dalam waktu relatif singkat dalam pembelajaran dikelas. Mahasiswa harus didorong dalam aktifitas kegiatan pembelajaran yang membuka cara berpikirnya dalam mempelajari materi perkuliahan. Mahasiswa cenderung pasif dalam menerima semua informasi yang ada dalam pertemuan perkuliahan tatap muka dikelas dengan hanya terfokus pada materi yang sedang dibahas pada makalah atau power point yang dipresentasikan. Mahasiswa perlu bahan ajar dalam mendukung kegiatan pembelajaran dikelas, sehingga mahasiswa dapat menyaring kebenaran informasi yang diterima. Berpikir kritis adalah proses menganalisa dan 
mengevaluasi pemikiran secara mandiri berdsarkan informasi yang diterima (Paul, 2012).

Kemampun berpikir kritis mahasiswa dilihat dari kualitas pertanyaan dan jawaban pada saat pembelajaran berlangsung. Mahasiswa menggunakan daya nalar dalam menangapi informasi yang diterima dalam pikirannya. Kemampuan berpikir kritis mahasiswa dilihat berdasarkan hasil tes uraian mahasiswa berdasarkan bahan ajar ekologi hewan berbasis problem based learning yang dikembangkan (Lubis, 2017). Keterampilan berpikir kritis dilatih dengan menganalisis data-data perubahan lingkungan lokal yang disajikan di bahan ajar untuk melatih keterampilan berpikir kritis (Mukhyati dan Sriyati, 2015).

Pembelajaran yang dilaksanakan menggunakan bahan ajar mendukung kegiatan ilmiah, yang memberikan kebiasaan terhadap mahasiswa dalam menganalisa kegiatan yang dilakukan. Mahasiswa dapat berpikir kritis dan mencermati setiap proses kegiatan yang dilaksanakan, kemudian membangun proses kemampuan berpikir kritis. Melalui proses pembelajaran metode ilmiah dengan menemukan jawaban ilmiah sesuai dengan konsep materi, mahasiswa akan memunculkan kemampuannya untuk berpikir kritis (Batubara, dkk., 2016).

Kemampuan pemecahan masalah mahasiswa signifikan terhadap hasil belajar yang diperoleh. Selama kegiatan proses belajar mengajar dikelas mahasiswa terbiasa dengan praktik memecahkan permasalahan sesuai dengan konteks isi bahan ajar ekologi hewan. Mahasiswa sering melakukan praktik dengan nyata berdasarkan pada teori yang dipelajari dimatakuliah ekologi hewan. Bahan ajar ekologi hewan berbasis problem based learning dapat menuntun mahasiswa melakukan pemecahan masalah dengan memberikan pengalaman secara nyata kepada mahasiswa dalam pembelajaran. Problem based learning pembelajaran yang menggunakan pendekatan learner centered, dimana mahasiswa diberikan aktifitas dalam melakukan penelitian, mengintegrasikan teori dan praktik, dan mengaplikasikan pengetahuan dan keterampilan untuk membangun solusi terhadap suatu permasalahan (Savery, 2006). Problem based learning pembelajaran yang menyajikan berbagai permasalahan yang autentik dan bermakna kepada peserta didik, yang berfungsi untuk mendorong peserta didik melaksanakan investigasi atau penyelidikan (Arends, 2008).

Mahasiswa dapat mempelajari materi ekologi hewan berdasarkan literatur buku teks, jurnal penelitian dan aktifitas kegiatan mahasiswa untuk memecahkan masalah sesuai dengan lingkungan sekitar. Mahasiswa terdorong dengan kegiatan pemecahan masalah yang disajikan dalam bahan ajar yang dikembangkan. Problem based learning mampu membangkitkan diskusi dan dapat meningkatkan kemampuan berpikir kritis dan hasil belajar. Problem based learning menumbuhkan kemampuan berpikir kritis, analitis, sistematis, dan logis dalam menemukan alternatif pemecahan masalah (Naputri, dkk., 2016).

Kemampuan pemecahan masalah dapat menjadi kompetensi yang melekat pada diri mahasiswa selama dalam kegiatan perkulihan. Mahasiswa dengan diberikan variasi permasalahan baru dan dinamis sesuai dengan perkembangan ilmu dan kondisi yang dihadapi. Bahan ajar ekologi hewan dikemas dengan sajian permasalahan yang unik dan menarik minat mahasiswa untuk dipecahkan. Bahan ajar ekologi hewan berbasis problem based learning sebagai media dalam kegiatan proses perkuliahan memberikan peningkatkan kemampuan mahasiswa dalam memecahkan masalah.

\section{KESIMPULAN}


Bahan ajar ekologi hewan berbasis problem based learning efektif meningkatkan kemampuan berpikir kritis dan pemecahaan masalah mahasiswa Pendidikan Biologi pada matakuliah Ekologi Hewan. Kemampuan berpikir kritis berdasarkan Uji hipotesis menggunakan uji statistik one sample $t$ test Sig (2 tailed) $(0,00) \leq \alpha \quad(0,05)$ dengan $\mathrm{H}_{\mathrm{a}}$ diterima, signifikan perbedaan rata hasil kemampuan berpikir kritis mahasiswa dengan menggunakan bahan ajar ekologi hewan berbasis problem based learning. Kemampuan pemecahan masalah Sig (2 tailed) $(0,00) \leq \alpha(0,05)$ dengan $\mathrm{H}_{\mathrm{a}}$ diterima; signifikan perbedaan rata - rata hasil kemampuan pemecahan masalah mahasiswa menggunakan bahan ajar ekologi hewan berbasis problem based learning.

\section{UCAPAN TERIMAKASIH}

Ucapan terimakasih penulis ucapkan kepada LPPM dan PM Universitas Samudra dan seluruh Civitas Akademika Universitas Samudra serta pihak terkait yang telah memberikan dana ataupun bantuan lainnya dalam program Hibah Penelitian Dosen Muda (PDM) Universitas Samudra Tahun 2017.

\section{DAFTAR RUJUKAN}

Arends, R. 2008. Learning to Teach. Penerjemah: Helly Prajitno \& Sri Mulyani. McGraw Hill Company: Yogyakarta.

Batubara, A., Hasruddin dan R. Mulyana. 2016. Pengaruh Strategi Pembelajaran Inkuiri dan Discovery terhadap Kemampuan Berpikir Kritis dan Hasil Belajar Biologi Siswa pada Topik Bioteknologi di MAN I Padangsidimpuan. Jurnal Pendidikan Biologi, Vol. 5, No. 2.p. $32-38$

Bilgin, I., E. Senocak, dan M. Sozbilir. 2009. The Effects of Problem Learning Instructionn on university Student Performance of conceptual And Quantitive
Problem And Gaas Concept. Journal of Matemamatic Science and Technology Education. Vol 5 No. 2 p. $153-164$

Lubis, J. 2017. Pengaruh Penerapan Model Pembelajaran Problem Solving PadaKemampuan Berpikir Kritis Mahasiswa. Jurnal Pendidikan Biologi, Vol. 6, No. 2. p. 36-41

Mukhyati dan S. Sriyati. 2015. Pengembangan Bahan ajar Perubahan Lingkungan Berbasis Realitas Lokal dan Literasi Lingkungan. Seminar Nasional XII Pendidikan Biologi FKIP Universitas Sebelesa Maret.

Naputri, L., Syarifuddin, dan E. Djulia. 2016. Pengaruh Strategi Pembelajaran Berbasis Masalah dan Minat Belajar Terhadap Kemampuan Berpikir Kritis dan Hasil Belajar Siswa pada Materi Sistem Pencernaan Makanan Manusia di MAS Amaliyah Sunggal. Jurnal Pendidikan Biologi, Vol. 5, No. 2. p. 86-92

Nurhayati, L. Angraeni, dan Wahyudi. 2019. Pengaruh Model Problem Based Learning Kemampuan Berpikir Kritis Terhadap kemampuan berpikir tingkat tinggi. Edusains, Vol. 11, No. 2, p. $17-20$.

Paul, R. W. 2012. Critical Thinking: What Every Person Needs To Survive in a Rapidly Changing World. Tomales: Foundation for Critical Thinking

Purwanto., R. Aristo, dan L. Suharto. 2007. Pengembangan Modul: Seri Teknologi Pembelajaran. Jakarta: Departemen Pendidikan Nasional Pusat Teknologi Informasi dan Komunikasi Pendidikan.

Savery, J. R. 2006. Overview of Problem-based Learning: Definitions and Distinctions. The Interdisciplinary Journal of 
Problem-based Learning, 1(1):

9-20, (Online), (http://docs.lib.purdue.edu/cgi), diakses 20 Februari 2017.

Tivani, I dan Paidi. 2016. Pengembangan LKS Biologi Berbasis Masalah untuk Meningkatkan Kemampuan Pemecahan Masalah dan Karakter Peduli Lingkungan. Jurnal Inovasi Pendidikan IPA. Vol 2 No. 1 p. 35-45.

doi:http://dx.doi.org/10.21831/ji pi.v2i1.8804.

Toy, B. A. I., F. K. Ferry, F. C. Junet, F. L. Jerry. \& S. R. Ferdy. 2018. Desian Bahan Ajar Biologi Berbasis Discovery Learning dengan Scientific Approach untuk Materi Jamur dikelas X SMA. Biosfer: Jurnal Pendidikan Biologi, 11 (1), 6775.
Wijayanti, T. F. dan S. Nawawi. 2017. Efektivitas Modul Sistem Reproduksi Berbasis Berpikir Kritis Terintegrasi Nilai Islam dan Kemuhammadiyahan Terhadap Keterampilan Berpikir Kritis. Jurnal Bioedukasi. Vol. 8 No. 2 p.176-185 